\title{
Contents, Vol. 39, 1995
}

Official Journal of the Federation of European Nutrition Societies (FENS)

Annals of

Nutrition \& Metabolism

European Journal of Nutrition, Metabolic Diseases and Dietetics Journal européen de nutrition, des maladies metaboliques et de diététique Europäische Zeitschrift $\mathrm{f}$ ür Ernährungswissenschaft, Stoffwechselstorungen und Diätetik

Annals of Nutrition and Metabolism (formerly 'Annales de la Nutrition et de $\Gamma$ Alimentation' and 'Nutrition and Metabolism') is recognised by the 'Federation of European Nutrition Societies' (FENS) as its official journal

Founded 1959 as 'Nutritio et Dieta' by E. Azerad, H. Kapp and J. Trémolières

Former Main Editor: A. Wretlind (1961 -1969)

Continued 1970-1990 by N. Zöllner

Continued as 'Nutrition and Metabolism' (1970-1980)

Since 1980 integrating 'Annales de la Nutrition et de ГAlimentation'

Main Editor

G. Wolfram, Freising

Associate Editor

G. Debry, Nancy

Editorial Board

L.G. Alcindor, Paris C. Barth, Potsdam B. Brubacher, Basel Ch. Frayssinet, Villejuif P. Fürst, Stuttgart/Hohenheim L. Gueguen, Jouy-en-Josas J. Hautvast, Wageningen K. Hellström,

Stockholm F.A. Hommes, Augusta, Ga. B. Jacotot, Créteil

I. Macdonald, London

C.F. Mills, Aberdeen

DJ. Naismith, London

G. Schlierf, Heidelberg

A.P. Simopoulos, Washington, D.C.

M.A. Spadoni, Roma

A.St. Truswell, Sydney

W. Waldhäusl, Vienna

A. Yoshida, Nagoya

Advisory Board, FENS

Austria

B.M. Brandstetter, Vienna

L. Balabanski, Sofia

Denmark

E. Aaes-Jørgensen, København

Finland 
E.H. Koskinen, Helsinki

Germany

G. Schlierf, Heidelberg

Great Britain

J. Dickerson, Guildford

Greece

A. Trichopoulou, Athens

Italy

E. Lanzola, Pavia

Netherlands

R.J.J. Hermus, Boven-Leeuwen

Norway

K.R. Norum, Oslo

Poland

S. Berger, Warzawa

Spain

G. Varela, Madrid

Sweden

L. Hambraeus, Uppsala

Switzerland

E. Jéquier, Lausanne

KARGER

Contents Vol. 39,1995

No. 1

Original Paper

Oxidized Low-Density Lipoproteins Delay 1

Endothelial Wound Healing: Lack of Effect of Vitamin E Boissonneault, G.A.; Wang, Y.; Hong

Chung, B.

Serum Lipids in Children with Xeroderma from 9

an Inland District of Sri Lanka

Christiansen, E.N.; Skåra, B.B.; Sørensen, E.; Gray, H.J.

Utilisation nutritionnelle des protéines de la 16

lentille chez le jeune rat Combe, E.; Cvirn, M.

Enzymes of the Gamma-Glutamyl Cycle Are

28

Programmed in utero by Maternal Nutrition Langley-Evans, S.C.; Wood, S.; Jackson, A.A.

Do trans Fatty Acids Impair Linoleic Acid 36

Metabolism in Children? Decsi, T.; Koletzko, B.

Early Biochemical Events in Mice Exposed to

Cycas and Fed a Nigerian-Like Diet Eriyamremu, G.E.; Osagie, V.E.; Alufa, O.I.; Osaghae, M.O.; Oyibu, F.A.

Influence of Dietary Supplementation with Fish 52 on Plasma Fatty Acid Composition in Coronary Heart Disease Patients

Santos, M.J.; López-Jurado, M.; Llopis, J.; Urbano, G.; Mataix, F.J.

Resistance to Oxidation of Native Lipoproteins 63 and Erythrocyte Membrane Lipids in Rats with Iron Overload

Antébi, H.; Pages, N.; Zimmermann, L.; Bourcier, C; Fléchet, B.; Alcindor, L.-G. 
Acknowledgement 69

Announcements $\quad 70$

No. 2

Original Paper

Effect of Acute Glycerol Administration with or 71 without a Mixed Meal in Humans Nicolaïew, N.; Cavallero, E.; Gandjini, H.; Dole, E.; Koziet, J.; Gambert, P.; Francois, A.; Jacotot, B.

Calculated Iodine Intake before and after Simu- 85

lated Iodization (Dutch Nutrition Surveillance

System)

Brussaard, J.H.; Hulshof, K.F.A.M.; Löwik, M.R.H.

Effect of Vitamin D Repletion on Testicular 95

Function in Vitamin D-Deficient Rats Sood, S.; Reghunandanan, R.; Reghunandanan, V.; Marya, R.K.; Singh, P.I.

Effect of Dietary Antioxidants on the Susceptibil- 99 ity to Hepatic Microsomal Lipid

Peroxidation in the Rat

Yamamoto, K.; Fukuda, N.; Shiroi, S.; Shiotsuki, Y.; Nagata, Y.; Tani, T.; Sakai, T.

Broiler Chick Responses to Anorectic Agents:

107

Dietary Acetic and Propionic Acids and the Blood Metabolites Pinchasov, Y.; Elmaliah, S.

Comparison of Recovery of Previously 117

Depressed Hepatic $\Delta 6$ Desaturase Activity in Adult and Old Rats Dinh, L.; Bourre, J.M.;

Dumont, O.; Durand, G

Risk and Benefit of Low Fat Intake in Vobecky, J.S.; Vobecky, J.; Normand, L.

Childhood

124

Announcement

134

No. 3

Original Paper

Comparison of Changes in Energy Expenditure 135

and Body Temperatures after Caffeine

Consumption

Koot, P.; Deurenberg, P.

Differential Incorporation of 13C Label from 143

Dietary Glucose into Neutral Sugars of Rat Intestine Macromolecules Rambal, C; Pachiaudi, C;

Normand, S,; Riou, J.-P.; Louisot, P.; Martin, A.

Effect of Chronic Ethanol Administration and 152 Dietary Protein Regimens on Intestinal

Absorption of Macromolecules in Rats Kaur, J.; Nagpaul, J.P.; Singh, K.; Mahmood, A. 
11

Comparison of Fluoxetine and Placebo in the $\quad 159$

Treatment of Obesity Fernández-Soto, M.L.; Gonzáles-Jiménez, A.; Barredo-Acedo, F.; Luna del Castillo, J.D.; Escobar-Jimenez, F.

Response of the Calf Pancreas to Differently 164

Processed Soya Bean and Pea Diets Le Dréan, G.; Le Huërou-Luron, I.; Philouze-Romé, V.;

Foullec, R.; Guilloteau, P.

Determination of Intracellular Water by Multi- 177 frequency Bioelectrical Impedance De

Lorenzo, A.; Candeloro, N.; Andreoli, A.; Deurenberg, P.

Differential Effects of Geometrical Isomers of 185 Octadecadienoic Acids on Ketogenesis and

Lipid Secretion in the Livers from Rats Fed a Cholesterol-Enriched Diet Fukuda, R; Etoh, F.;

Wada, K.; Hidaka, F.; Yamamoto, K.; Ikeda, I.; Sugano, M.

Effects of Adaptation to Dietary Fat on Fatty193

Acid Composition of Serum and Serum Lipids in Miniature Swine

Seiquer, I.; Manas, M.; Ballesta, M.C.; Mataix, F.J.; Martinez-Victoria, E.

Announcement $\quad 176$

Copper Malabsorption after Intestinal Resection 227

in Rats. Effects of Cholecalciferol and Ascorbic

Acid

Hartiti, S.; López-Aliaga, I.; Lisbona, F.;

Barrionuevo, M.M.; Alférez, M.J.M.;

Gómez-Avala, A.E.; Pallarés, I.; Campos, M.S.

Validity of Predicted Total Body Water and 234

Extracellular Water Using Multifrequency Bioelectrical Impedance in an Ethiopian Population

Deurenberg, P.; Wolde-Gebriel, Z.; Schouten, F.J.M.

Validation of Extracellular Water Determination 242

by Bioelectrical Impedance Analysis in Growth

Hormone-Deficient Adults

Snel, Y.E.M.; Brummer, R.-J.M; Doerga, M.E.;

Zelissen, P.M.J.; Koppeschaar, H.P.F.

Serum Phospholipid Fatty Acids in Severely 251

Injured Patients on Total Parenteral Nutrition

with Medium Chain/Long Chain Triglyceride

Emulsions

Adolph, M.; Hailer, S.; Eckart, J.

No. 5

No. 4

Original Paper

Effect of Postexercise Sucrose Administration on 203 Liver Glycogen Repletion in Rats

Litvinova, L.; Viru, A.

Vitamin Intakes (A, E, C, Carotenes) in a French 208

Institution: Assessment by the Duplicate-Diet

Method

Ravel, A.; Poupard, A.; Roussel, A.M.; Alary, J. 
Magnesium and Ascorbic Acid Supplementation 217 in Diabetes mellitus Eriksson, J.;

Kohvakka, A.

Determination of Riboflavin and Flavoco- 224

enzymes in Human Blood Plasma by High-Performance Liquid Chromatography Zempleni, J.

Original Paper

Serum Fatty Acid Composition in Normal Japa- 261 nese and Its Relationship with Dietary Fish and Vegetable Oil Contents and Blood Lipid Levels Nakamura, T.; Takebe, K.; Tando, Y.; Arai, Y.; Yamada, N.; Ishii, M.; Kikuchi, H.; Machida, K.; Imamura, K.-i.; Ferada, A.

Macronutrient, Copper, and Zinc Intakes of 271

Young German Children as Determined by Duplicate Food Samples and Diet Records Laryea, M.D.; Schnittert, B.; Kersting, M.; Wilhelm, M.; Lombeck, I.

Tissue Distribution of (8-14C)-Octacosanol in 279

Liver and Muscle of Rats after Serial Administration Kabir, Y.; Kimura, S.

Effect of Pyridoxine and Magnesium on Stress- 285 Induced Gastric Ulcers in Mice Selected for Low or High Blood Magnesium Levels Henrotte, J.G.; Aymard, N.; Allix, M.; Boulu, R.G.

111

A Diet Moderately Enriched in Phytosterols 291

Lowers Plasma Cholesterol Concentrations in Normocholesterolemic Humans Pelletier, X.;

Belbraouet, S.; Mirabel, D.; Mordret, F.; Perrin, J.L.; Pages, X.; Debry, G.

Vitamin E in Intestinal Fat Malabsorption 296

Singh Ghalaut, V.; Singh Ghalaut, P.; Kharb, S.; Singh, G.P.

$\alpha$-Tocopherol and Phospholipase A2 in Liver and 302 Brain of Chicks Posthatching: The

Influence of Dietary Fat and Vitamin E Fuhrmann, H.; Sallmann, H.P.

Effect of Different Levels of an Ascorbic Acid 310

and Tea Mixture on Nonheme Iron Absorption

from a Typical Tunisian Meal Fed to Healthy

Rats

Hamdaoui, M:, Doghri, T.; Tritar, B.

Effects of the Beta-Adrenergic Agonist Salbuta- $317 \mathrm{~mol}$ and Its Withdrawal on Protein

Metabolism of Lambs

del Barrio, A.S.; García-Calonge, M.A.; Fernández-Quintela, A.; Simon, E.; Portillo, M.P.; Astiasarán, I.; Martinez, J.A.

No. 6 Review

325

Body Composition: Overview of Methods and Future Directions of Research Deurenberg, P.;

Schutz, Y.

Original Paper

Selected Vitamins and Trace Elements in Blood 334 of Vegetarians

Kxajcovicová-Kudlácková, M.; Simoncic, R.; Babinská, K.; Béderová, A.; Brtková, A.;

Magálová, T.; Grancicová, E.

Assessment of Nutritional Risk in the Elderly

Nikolaus, T.; Bach, M.; Siezen, S.; Volkert, D.; Oster, P.; Schlierf, G.

Protein Metabolism in Cirrhotic Rats: Effect of 346 Dietary Restriction

Holecek, M.; Skopec, F.; §prongl, L.

Fluorometric Riboflavin Titration in Plasma by 355 Riboflavin-Binding Apoprotein as a Method for Vitamin B2 Status Assessment Kodentsova, V.M.; Vrzhesinskaya, O.A.; Spirichev, V.B. 
Effect of Phytic Acid and Microbial Phytase on 361 Cd Accumulation, Zn Status, and Apparent Absorption of $\mathrm{Ca}, \mathrm{P}, \mathrm{Mg}, \mathrm{Fe}, \mathrm{Zn}, \mathrm{Cu}$, and $\mathrm{MN}$ in Growing Rats Rimbach, G.; Pallauf, J.; Brandt, K.; Most, E.

Eating Behavior and Energy and Nutrient Intake 371 in Overweight/Obese and Normal-Weight Spanish Elderly

Ortega, R.M.; Redondo, M.R.; Zamora, M.J.; López-Sobaler, A.M.; Andres, P.

Announcement $\quad 378$

Acknowledgement to the 1995 Reviewers 379

Author Index Vol. 39, 1995380

Subject Index Vol. 39, 1995382

\section{S. Karger}

Medical and Scientific Publishers Basel · Freiburg · Paris · London New York · New Delhi ·

Bangkok Singapore $\cdot$ Tokyo $\cdot$ Sydney

Drug Dosage

The authors and the publisher have exerted every effort to ensure that drug selection and dosage set forth in this text are in accord with current recommendations and practice at the time of publication. However, in view of ongoing research, changes in government regulations, and the constant flow of information relating to drug therapy and drug reactions, the reader is urged to check the package insert for each drug for any change in indications and dosage and for added warnings and precautions. This is particularly important when the recommended agent is a new and/or infrequently employed drug.

All rights reserved.

No part of this publication may be translated into other languages, reproduced or utilized in any form or by any means, electronic or mechanical, including photocopying, recording, microcopying, or by any information storage and retrieval system, without permission in writing from the publisher or, in the case of photocopying, direct payment of a specified fee to the Copyright Clearance Center (see 'Information for Readers and Subscribers').

(C) Copyright 1995-96 by S. Karger AG, P.O. Box, CH-4009 Basel (Switzerland) Printed in Switzerland on acid-free paper by Thür AG Offsetdruck, Pratteln

IV 